\title{
Molecular Phylodiagnosis of Taenia hydatigena from Stray Dogs in Erbil Province-Kurdistan Region/Iraq
}

\author{
Zuber I. Hassan* \\ Department of Medical Laboratory Techniques, Shaqlawa Technical College, Erbil Polytechnic University, Erbil, Kurdistan Region, Iraq
}

\author{
${ }^{*}$ Corresponding author: \\ Zuber I. Hassan, \\ Department of Medical \\ Laboratory Techniques, \\ Shaqlawa Technical College, \\ Erbil Polytechnic University, \\ Erbil, Kurdistan Region, Iraq. \\ E-mail: zuberismail@epu. \\ edu.iq
}

Received: 17 March 2021

Accepted: 15 June 2021

Published: 30 December 2021

\section{DOI}

10.25156/pty.v11n2y2021.pp26-30

\section{A B S T R A C T}

Taenia hydatigena is one of the most prevalent taeniid species of livestock and dogs. A total of 52 fecal samples were collected from September 2019 to May 2020. The highest prevalence rate was observed in Rural area $(21.15 \%, 11 / 52)$, as compared to Urban area $(15.38 \%, 8 / 52)$. Nineteen ( 9 males and 10 females) out of 52 dogs were infected with $T$. hydatigena; there were no significant differences in prevalence based on molecular technique was observed between females $(19.23 \%)$ and males $(17.31 \%)$. The DNA's of taeniid eggs were extracted, amplified, and sequenced by targeting of mitochondrial cytochrome $c$ oxidase subunit 1 (cox 1$)$. The partial nucleotide sequence was submitted to the GenBank and recorded under accession number (MT298194-MT298197). Molecular analysis indicates that the specimens characterized in this study belong to the same species and shared greater 98.71-100\% identity with cox 1 sequences of $T$. hydatigena. This is the first molecular diagnosis of $T$. hydatigena in the stray dogs at Erbil Province. The data are a useful for health and educational authorities responsible for designing and implementing effective measures for disease control.

Keywords: Cytochrome c oxidase subunit 1; Phylogram; Stray dogs-Erbil; Taenia hydatigena

\section{INTRODUCTION}

Taenia bydatigena is a cosmopolitan and Member of the genus Taenia, which is the most important cyclophyllidean tapeworms (Gomez-Puerta et al., 2015). It is responsible for major medical and economic losses in animals (Ulziijargala et al., 2020), due to widespread parasite that can infect a wide range of herbivorous animals with its larval stage, Cysticercus tenuicollis (Myczkaa et al., 2019; AbouLaila et al., 2020). Furthermore, adult worms parasitize mostly present in small intestine of canids and produce eggs, which are infective to intermediate hosts (Mirbadie et al., 2019; Zhu et al., 2019). Taeniid tapeworms associated with the sheepdog life cycle. The disease in sheep-rearing countries is most prevalent; due to high number of stray dogs, and improper disposal of slaughtered home offal (Haddawee et al., 2018). Previous studies have indicated that $T$. bydatigena is one of the most prevalent Taenia species in dogs in Iraq (Faraj and Al-Amery, 2018), Iran (Emamapour et al., 2015), Turkey (Oguz et al., 2018), Russia (Moskvina and Ermolenko, 2016), and Italy (Liberato et al., 2018). The family Taeniidae (Echinococcus and Taenia) is the similarity of their eggs, in which they are microscopically indistinguishable (Mirbadie et al., 2019).

Taxonomy is a classical and essential system for organizing biodiversity (Boubaker et al., 2016). Recent advances in bioinformatics based on automated DNA sequencing and statistical computer algorithms have radically altered how organisms are classified and how evolutionary relationships from higher taxa to species and populations can be reconstructed (Nakao et al., 2013; Zhu et al., 2019). In general, a few studies conducted mostly using partial mitochondrial cytochrome c oxidase subunit 1 (cox1) and nad1 gene sequences have reported considerable levels of genetic variation among T. bydatigena populations from different geographical regions and hosts (Rostami et al., 2013; Omar et al., 2016; Muku et al., 2020). Polymerase chain reaction (PCR) assays have been widely used to detect and differentiate different species of parasites (Kilinc et al., 2019). The simplicity of this diagnostic tool and high-efficiency enabling for determination of parasite infection during the high patent period, as well as the pre- or late- patent infection period (Wang et al., 2018; Trasviña-Muñoz et al., 2020). This study was conducted to identify the strain of $T$. bydatigena from stray dogs of Erbil Province using the mitochondrial $\operatorname{cox} 1$ gene sequence.

\section{MATERIALS AND METHODS}

\section{Sample Collection and Egg Isolation}

The study was carried out from September 2019 to May 2020, In this study, stray dogs were the street dogs is defined as any dog roaming in a public place without its owner or a person who is not responsible for it, was not treated for worms and usually fed on garbage. Fecal 
samples were collected from both 18 male and 34 female dogs at different age groups. All animals were subjected to mandatory quarantine. During the first defecation of the animals, excrement was collected at the shelter. The whole stool was placed into a disposable plastic container, labeled, and transferred to the laboratory.

\section{Detection of Taeniid-positive Egg Fecal Samples}

Fifty-two fecal samples were collected and determined by the flotation and PCR technique from stray dogs, respectively. The fecal samples were filtered through double gauze in centrifuge tubes of $15 \mathrm{~mL}$ and were concentrated by centrifugation at $12,000 \times \mathrm{g}$ for $15 \mathrm{~min}$. The eggs at the pellet were washed 3 times with PBS pH 7.4 by centrifugation at $1000 \times \mathrm{g}$ during $15 \mathrm{~min}$. The precipitation was placed into a plastic tube and suspended in a Zinc sulfate solution (specific gravity 1.250), and Lugol's iodine was added to help in the identification of protozoan cysts and coccidial oocysts (Neves et al., 2014). A coverslip was then placed on the top of each tube and the tubes were left for $1 \mathrm{~h}$ to allow the eggs to float and attach. The eggs were visualized and characterized by microscope as shown in Figure 1 and sorted using a capillary ( $0.5 \mathrm{~mm}$ in diameter) to avoid proglottids or other impurities at $-20^{\circ} \mathrm{C}$ until further analysis. The adult worms were obtained from nine naturally infected dogs after treatment with albendazole, at a dose of $0.3 \% \mathrm{~g} / \mathrm{kg}$ body weight (Faraj and Al-Amery, 2018) as shown in Figure 2.DNA Analysis and PCR Amplification

Genomic DNA eggs were extracted using the QIAamp DNA Stool Mini kit (Qiagen, Germany) according to the manufacturer's instructions. DNA elution was completed to $100 \mu \mathrm{l}$ with Nuclease-Free water and stored at $-20^{\circ} \mathrm{C}$. The cox 1 gene was amplified by PCR using previously published primer, JB3 (forward): 5'T'T'TTTTGGGCATCCTGAGGTTTAT-3' and JB4.5 (reverse): 5'TAAAGAAAGAACATAATGAAAATG-3'to amplify 446bp for the T. bydatigena (Hama et al., 2018). The amplification reaction mixture $(25 \mu \mathrm{l})$ consisted of $12.5 \mu \mathrm{l}$ of $(2 \times)$ Go-Tag master mix, $20 \mathrm{pmol}(2 \mu \mathrm{l})$ of each primer (forward and reverse), $2 \mu$ l of template DNA, and $6.5 \mu \mathrm{l}$

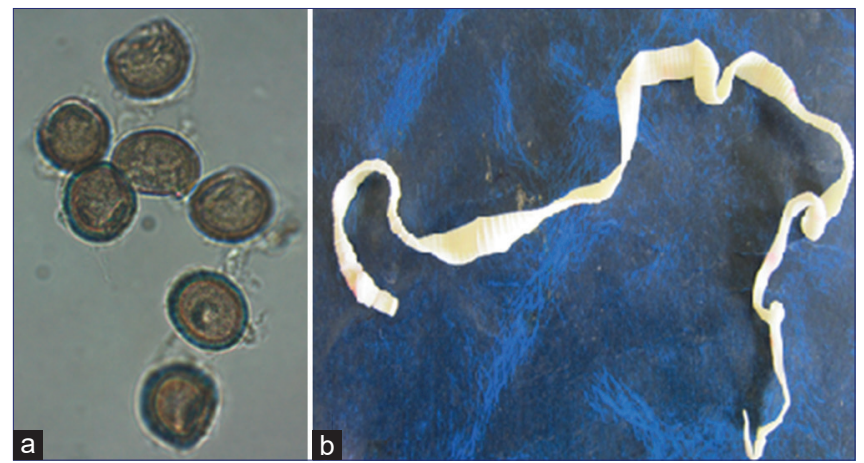

Figure 1: Show (a) Eggs of Taenia spp. (b) Adult worm of Taenia hydatigena without stain nuclease-free water. The amplification reaction was carried out under the following conditions: a pre-amplification step at $94^{\circ} \mathrm{C}$ for $5 \mathrm{~min}$, followed by 35 cycles with denaturing at $94^{\circ} \mathrm{C}$ for the $30 \mathrm{~s}$, annealing at $55^{\circ} \mathrm{C}$ for $30 \mathrm{~s}$ and extension at $72^{\circ} \mathrm{C}$ for $45 \mathrm{~s}$, and the final elongation of DNA strands, an ending-extension at $72^{\circ} \mathrm{C}$ for $10 \mathrm{~min}$. Water instead of DNA was included in each set of PCR reactions as negative control. The PCR products were visualized by using $1.5 \%$ agarose gel electrophoresis (Promega, USA) at 100 volts for $55 \mathrm{~min}$ in $1 \times$ TAE buffer (2M Tris-acetate, $50 \mathrm{mM}$ EDTA). The amplified products were commercially sequenced in both directions (Macrogen Inc. South Korea), and the generated sequences were examined using Accelrys Gene 2.5 program (Accelrys, Cambridge, UK) and compared against the NCBI database through the use of BLAST algorithm (http://www.ncbi.nlm.nih.gov/BLAST/).

\section{Nucleotide Sequence and Phylogenetic Tree Analysis} The species of Taenia was confirmed by analyzing the nucleotide sequences of the cox1gene. The sequences were aligned through the ClustalW algorithm (Thompson et al., 1994), provided by BioEdit v7.2.5 (Hall, 1999), with sequences available in the GenBank (NCBI) database. Nucleotide sequences of the partial $\operatorname{cox} 1$ gene of the $T$. bydatigena from stray dogs were deposited in the GenBank database under accession numbers MT298194- MT298197 through the use of BLAST algorithm (http://www. ncbi.nlm.nih.gov/BLAST). Phylogenetic analyses were performed on individual partial gene sequences using MEGA software (Molecular Evolutionary Genetics Analysis 3.1; http:/ / www.megasoftware and the neighborjoining were used to build the tree.

\section{RESULTS}

Out of 52 fecal samples from stray dogs were analyzed for the presence of T. bydatigena, 14 (26.92\%) and $19(36.54 \%)$

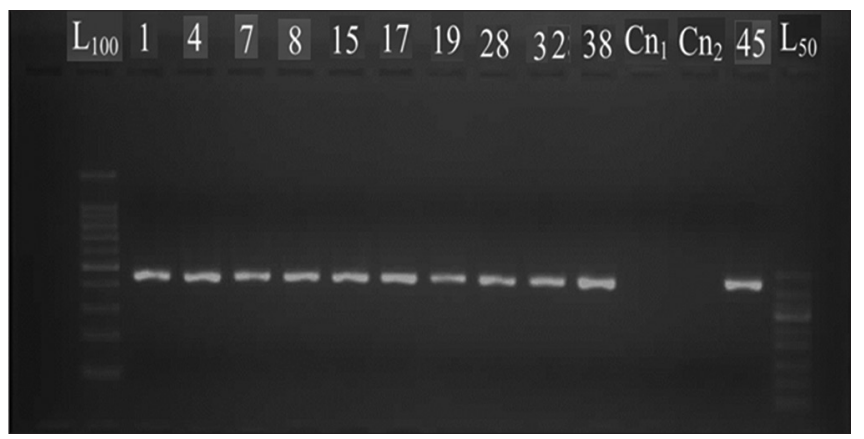

Figure 2: Gel electrophoresis from polymerase chain reaction (PCR) amplification of Taenia hydatigena. DNA marker size (50bp DNA ladder), $\left(\mathrm{L}_{100}\right)$, DNA marker size (100-bp DNA ladder), $\left(\mathrm{L}_{50}\right)$ Cn1=Control DNA extraction, Cn2=Control negative PCR, lanes 1, 4, 7, 8, 15, 17, 19, 28, 32, 38 and 45-specific product for Taenia hydatigena isolated from dog faces 
were positive by centrifugation-flotation test and PCR technique, respectively. The highest prevalence rate was observed in the Rural area $(21.15 \%, 11 / 52)$, while the lowest was in Urban $(15.38 \%, 8 / 52)$, respectively. However, no significant differences (0.999) were found between the two different areas. Furthermore, the highest rate of infection was found in females $(19.23 \%)$ as compared to male stray dogs $(17.31 \%)$ as shown in Table 1.

The amplification of the fragment occurred in 100\% of the taeniid egg samples. As well as, the expected patterns were obtained in the samples with eggs of Taenia spp. as shown in Figure 2. The result was corresponding with $T$. bydatigena as the multiple sequences alignment of the nucleotide with (Boufana et al., 2015) ID: KT372519 as shown in Figure 3. It revealed that, five isolates ( $\operatorname{dog} 8.9$,
28, 38, and 49) under the accession number (MT298196) showed $100 \%$ identity to T. bydatigena (KT372519) and six isolates ( $\operatorname{dog} 4,6,7,11,19$ and 45) under the accession number (MT298195) showed 99.49\% identity with T. bydatigena due to nucleotide changes $(\mathrm{T} \rightarrow \mathrm{C})$ at position 41 and $(\mathrm{T} \rightarrow \mathrm{A})$ at position 78 . The similarity MT298194 (dog 1, 3, 15, 27 and 32) and KT372519 was 99.23\% due to nucleotide changes $(\mathrm{T} \rightarrow \mathrm{C})$ at position 41 and 216 and $(\mathrm{T} \rightarrow \mathrm{A}$ ) at position 78, and finally, the difference between MT298197 (dog 10, 17, and 31) and KT372519 was $1.29 \%$ due to multiple nucleotide changes at position 36 and 41 $(\mathrm{T} \rightarrow \mathrm{C}),(\mathrm{T} \rightarrow \mathrm{A})$ at position $78,(\mathrm{G} \rightarrow \mathrm{A})$ at position 210 , and $(\mathrm{G} \rightarrow \mathrm{T})$ at position 300 . Figure 4 shows the phylogenetic tree of the dog fecal samples with reference sequences KT372519, MN478491, MN175599, MT086496, MN216152, MN478491, MH638348, MN114527, JN831304, KP641176, JQ710588, and KF268023).

Table 1: Prevalence of Taenia hydatigena in stray dogs at Erbil Province

\begin{tabular}{lccccc} 
Variables & No. of tested dogs & $\begin{array}{c}\text { Positive no. fecal } \\
\text { centrifugal flotation test }\end{array}$ & Percentage & Positive no. by PCR & Positive no. by PCR \\
$\begin{array}{l}\text { Address } \\
\text { Urban }\end{array}$ & 22 & 6 & 11.54 & 8 & 11 \\
Rural & 30 & 8 & 15.38 & & 21.15 \\
Gender & & & & 9 & 13.31 \\
Male & 18 & 7 & 13.46 & 10 & 19.23 \\
Female & 34 & 7 & 26.92 & 19 & 36.54 \\
Total & 52 & 14 & & & \\
\hline
\end{tabular}

$(P<0.05)$, PCR: Polymerase chain reaction

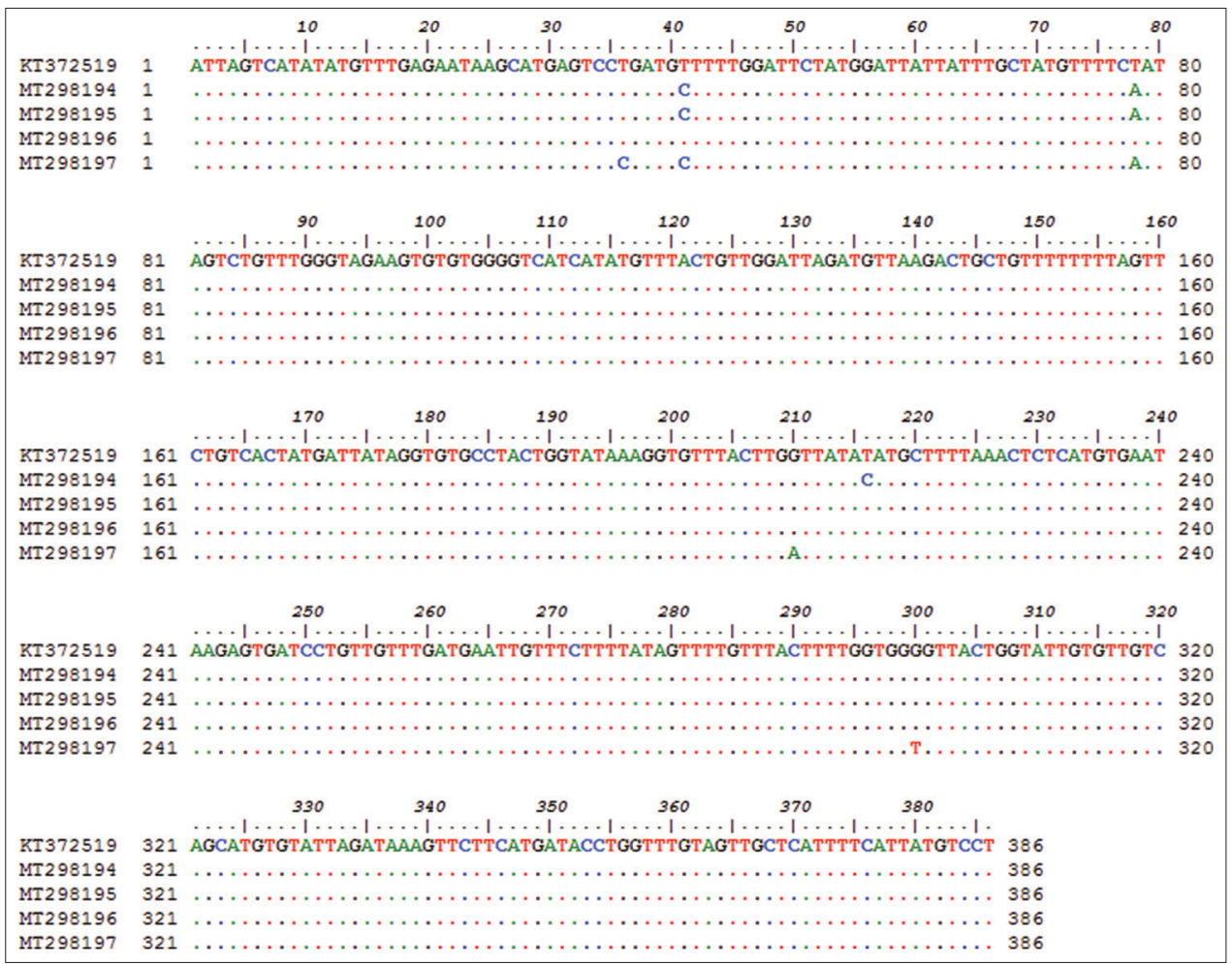

Figure 3: Alignment of a fragment of Taenia hydatigena (MT298194-MT298197) with GenBank accession number KT372519 


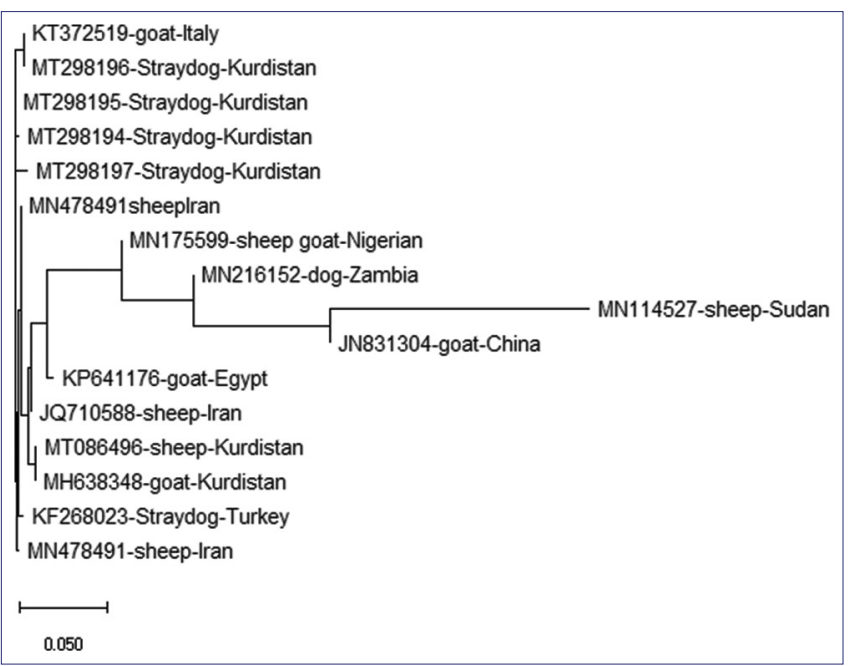

Figure 4: Phylogenetic tree of representative sequences of Taenia hydatigena from Erbil province and reference sequences of other genotypes. The tree was obtained by neighbor-joining analysis using partial sequences from cox1 gene

\section{DISCUSSION}

Epidemiological study of the zoonotic parasite is important for minimization of the risk to domestic animals (Liberato et al., 2018). The overall prevalence of T. bydatigena infections found in this study was $26.92 \%$ were positive by the flotation test. Previous studies conducted in Iran showed that the most prevalent rate $(43 \%)$ observed parasite was T. bydatigena (Emamapour et al., 2015). These may be due to no health control measures and their habits exposed to natural infection more than owned dogs. The prevalence rate $(32.54 \%)$ by molecular method (PCR), these agreed with (Zhu et al., 2019), who showed that no cross-reactivity was observed with other tapeworms inhabiting the small intestine as well as with each other. The minimum detected DNA ranged from 0.1 to $1 \mathrm{ng}$, low enough to produce results in case of low DNA yield (Mirbadie et al., 2019). Besides, the highest rate of infection was found in female $(19.23 \%)$ as compared to male stray dogs $(17.31 \%)$, these agreed with (Trasvina-Munoz et al., 2020) who showed that the highest rate was found in female $3 \%$ and the lowest rate was found in male stray dogs $2.6 \%$ at Northwestern Mexico by molecular method. As it does not seem to be any biological plausibility, we cannot exclude a selection bias due to the passive recruitment of the sampled dogs (Liberato et al., 2018).

To confirm infections of taeniasis, PCR has also been used successfully with reportedly high sensitivity and specificity to detect the presence of $T$. bydatigena in fecal samples (Zhu et al., 2019). Mitochondrial DNA (mtDNA) has been widely applied for molecular population genetics and systematics as an important genetic marker (Faraj and Al-Amery, 2018). This is because of its simple structure, low level of reorganization, and rapid evolution (Hassan et al., 2017). Molecular analysis indicates that the specimens characterized in this study belong to the same species and shared a greater $98.71-100 \%$ identity with cox 1 sequences of T. bydatigena from GenBank (KT372519) as described by (Boufana et al., 2015). This represents the first molecular diagnosis of $T$. bydatigena in the stray dogs. Also, T. hydatigena in livestock is required for more extensive investigation of transmission. Dominant strains identification in the endemic regions and the determination of the prepatent periods of these strains is also vital for ensuring efficacy in control programs with the use of anti-parasitic drugs (Faraj and Al-Amery, 2018). The isolated parasite was phylogenetically compared to the reference parasite, based on the cox 1 gene coding sequence. The phylogenetic analysis demonstrated that the isolates share close homology with some reference strains isolated in Iraq (Hama et al., 2018); Iran (Rostami et al., 2013); Egypt (Omar et al., 2016); Sudan (Muku et al., 2020); Italy (Boufana et al., 2015) and Nigeria (Ohiolei et al., 2019). T. bydatigena is one of the most taeniid species among sheep and dogs. The parasite transmission among a range of intermediate host species could increase the chance of genetic variability within different populations of the parasite in the world (GomezPuerta et al., 2015; Federer et al., 2016; Wang et al., 2018; Hidalgo et al., 2019).

\section{CONCLUSION}

Dog feces contamination with T. bydatigena in Erbil Province is demonstrated at the molecular level for the first time. These feces also cause a potential risk to livestock health. For this reason, there is a need for centrally coordinated control and prevention methods against the infection.

\section{REFERENCES}

AbouLaila, M., A. S. Mohamed, T. Roshdey and A. El-Khatam. 2020. Infection rate and biochemical characterization of Cysticercus tenuicollis from sheep in Minoufiya Governorate, Egypt. Vet. Parasitol. 20: 1-6.

Boubaker, G., I. Marinova, F. Gori, A. Hizem, N. Müller, A. Casulli, L. E. J. Puebla, H. Babba, B. Gottstein and M. Spiliotis. 2016. A dual PCR-based sequencing $g$ approach for the identification and discrimination of Echinococcus and Taenia taxa. Mol. Cell. Probes. 30: 211-217.

Boufana, B., A. Scala, S. Lahmar, S. Pointing, P. S. Craig, G. Dessì, A. Zidda, A. P. Pipia and A. Varcasia. 2015. A preliminary investigation into the genetic variation and population structure of Taenia hydatigena from Sardinia, Italy. Vet. Parasitol. 214(12): 67-74.

Emamapour, S. R., H. Borji and A. A. Nagibi. 2015. An epidemiological survey on intestinal helminths of stray dogs in Mashhad, NorthEast of Iran. J. Parasit. Dis. 39(2): 266-271.

Faraj, A. A. and A. M. Al-Amery. 2018. Molecular identification of 
Taenia hydatigena isolated from domestic dogs in Baghdad city. Int. J. Biosci. 13(4): 71-77.

Federer, K., M. T. Armua-Fernandez, F. Gori, S. Hoby, C. Wenker and P. Deplazes. 2016. Detection of taeniid (Taenia spp., Echinococcus spp.) eggs contaminating vegetables and fruits sold in European markets and the risk for metacestode infections in captive primates. Int. J. Parasitol. 5(3): 249-253.

Gomez-Puerta, L. A., J. Pacheco, O. Gonzales-Viera, M. T. Lopez-Urbina and A. E. Gonzalez. 2015. The taruca (Hippocamelus antisensis) and the red brocket deer (Mazama americana) as intermediate hosts of Taenia hydatigena in Peru, morphological and molecular evidence. Vet. Parasitol. 212: 465-468.

Haddawee, R. H., I. M. Sulbi and Z. F. Abass. 2018. Prevalence of Cysticercus tenuicollis in slaughtered sheep and goats by season, sex, age, at Karbala abattoir, Iraq. Sci. J. Med. Res. 2(5): $52-56$.

Hall, T. A. 1999. BioEdit: A user-friendly biological sequence alignment editor and analysis program for Windows 95/98/NT. Nucleic Acids Symp. Ser. 41: 95-98.

Hama, A. A., R. H. Zorab, F. M. Ali, A. M. Salih and A. A. Hassan. 2018. Prevalence and Molecular Characterization of Cysticercus tenuicollis Isolated from Some Intermediate Host in KurdistanIraq. $2^{\text {nd }}$ International Conference on the Health and Medical Sciences. p177-182.

Hassan, Z. I., A. M. Meerkhan, B. Boufana, A. A. Hama, B. D. Ahmed, W. M. S. Mero, S. Orsten, M. Interisano, E. Pozio and C. Casulli. 2017. Two haplotype clusters of Echinococcus granulosus sensu stricto in Northern Iraq (Iraqi Kurdistan) support the hypothesis of a parasite cradle in the Middle East. Acta Trop. 172: 201-207.

Hidalgo, A., A. Melo, F. Romero, J. Villanueva, C. Carrasco, P. Jara, J. J. Venegas and F. Fonseca-Salamanca. 2019. A PCR-RFLP assay for discrimination of Echinococcus granulosus sensu stricto and Taenia spp. in dogs stool. Exp. Parasitol. 200: 42-47.

Kilinc, S. G., H. K. Kesik and S. Simsek. 2019. Molecular characterization and haplotypes of sheep and goat isolates of Cysticercus tenuicollis in Turkey. Parasitology. 146(8): 1048-1054.

Liberato, C. D., F. Berrilli, L. Odorizi, R. Scarcella, M. Barni, C. Amoruso, A. Scarit, M. M. Di Filippo, A. Carvelli, F. lacoponi and P. Scaramozzino. 2018. Parasites in stray dogs from Italy: Prevalence, risk factors and management concerns. Acta Parasitol. 63(1): 27-32.

Mirbadie, S. R. A. N. Nasab, M. A. Mohaghegh, P. Norouzia, M. Mirzaiif and A. Spotin. 2019. Molecular phylodiagnosis of Echinococcus granulosus sensu lato and Taenia hydatigena determined by mitochondrial Cox1 and SSU-rDNA markers in Iranian dogs: Indicating the first record of pig strain (G7) in definitive host in the Middle East. Comp. Immunol. Microbiol. Infect. Dis. 65: 88-95.

Moskvina, T. V. and A. V. Ermolenko. 2016. Helminth infections in domestic dogs from Russia. Vet. World. 9(11): 1248-1258.

Muku, R. J., H. Yan, J. A. Ohiolei, A. A. Saaid, S. Ahmed, W. Jia and B. Fu. 2020. Molecular identification of Taenia hydatigena from
Sheep in Khartoum, Sudan. Korean J. Parasitol. 58(1): 93-97.

Myczkaa, W., A. W. Jeżewskia, K. J. Filip-Hutscha, A. M. Pyzielb, J. Kowalc, A. W. Demiaszkiewicza and Z. Z. Laskowski. 2020. The morphological and molecular identification of the tapeworm, Taenia lynciscapreoli, in intermediate and definitive hosts in Poland. Parasit. Wildl. 11: 213-220.

Nakao, M., A. Lavikainen, T. Yanagid and A. Ito. 2013. Phylogenetic systematics of the genus Echinococcus (Cestoda: Taeniidae). Int. J. Parasitol. 43: 1017-1029.

Neves, D., L. Lobo, P. B. Simões and L. Cardoso. 2014. Frequency of intestinal parasites in pet dogs from an urban area (Greater Oporto, northern Portugal). Vet. Parasitol. 200: 295-298.

Oguz, B., N. Ozda, O. O. Kilinc and M. S. Deger. 2018. Preliminary studies on the prevalence and genotyping of Echinococcus granulosus infection in stray dogs in Van Province, Turkey. J. Vet. Res. 62: 497-502.

Ohiolei, J. A., J. Luka, G. Zhu, H. Yan, L. Li, A. A. Magaji, M. A. Alvi, Y. Wu, J. Li, B. Fu and W. Jia. 2019. First molecular description, phylogeny and genetic variation of Taenia hydatigena from Nigerian sheep and goats based on three mitochondrial genes. Parasit. Vectors. 12: 1-11.

Omar, M. A., L. O. Elmajdoub, M. S. Al-Aboody, A. M. EISify, A. M. Elkhtam and A. A. Hussien. 2016. Molecular characterization of Cysticercus tenuicollis of slaughtered livestock in Upper Egypt governorates. Asian Pac. J. Trop. Biomed. 6(8): 706-708.

Rostami, S., R. Salavati, R. N. Beech, Z. Babaei, M. Sharbatkhori, M. R. Baneshi, E. Hajialilo, H. Shad and M. F. Harandi. 2013. Molecular and morphological characterization of the tapeworm Taenia hydatigena (Pallas, 1766) in sheep from Iran. J. Helminthol. 89(2): 150-157.

Thompson, J. D., D. G. Higgins and T. J. Gibson. 1994. CLUSTAL W: Improving the sensitivity of progressive multiple sequence alignment through sequence weighting, position specific gap penalties and weight matrix choice. Nucleic Acids Res. 22: 4673-4680.

Trasviña-Muñoz, E., G. López-Valencia, F. J. Monge-Navarro, J. C. Herrera-Ramírez, P. Haro, S. D. Gómez-Gómez, J. A. Mercado-Rodríguez, C. A. Flores-Dueñas, S. A. Cueto-Gonzalez and M. Burquez-Escobedo. 2020. Detection of intestinal parasites in stray dogs from a farming and Cattle Region of Northwestern Mexico. Pathogens J. 9: 2-8.

Ulziijargala, G., C. Yeruultb, J. Khulanc, C. Gantsetsegd, T. Wandrae, H. Yamasakif and M. Narankhajid. 2020. Molecular identification of Taenia hydatigena and Mesocestoides species based on copro-DNA analysis of wild carnivores in Mongolia. Parasit. Wildl. 11: 72-82.

Wang, N., Y. Wanga, Q. Yeb, Y. Yangc, J. Wanc, C. Guoa, J. Zhana, X. Gua, W. Laia, Y. Xiea, X. Pengd G. Yang. 2018. Development of a direct PCR assay to detect Taenia multiceps eggs isolated from dog feces. Vet. Parasitol. 251: 7-11.

Zhu, G., L. Li, J. A. Ohiolei, Y. Wu, W. Li, N. Zhang, B. Fu, H. H. B. Yan and W. Jia. 2019. A multiplex PCR assay for the simultaneous detection of Taenia hydatigena, T. multiceps, T. pisiformis, and Dipylidium caninum infections. BMC Infect. Dis. 19(1): 854. 